\title{
KEBIJAKAN KRIMINAL NON-PENAL OJK DALAM MENGATASI KEJAHATAN CYBER MELALUI SISTEM PEER TO PEER LENDING
}

\author{
${ }^{1}$ Ifrani; ${ }^{2}$ M.Yasir Said \\ Fakultas Hukum, Universitas Lambung Mangkurat \\ Jl.Brigjen Hasan Basry, Kota Banjarmasin 70123 \\ ${ }^{1}$ Email: ifrani@ulm.ac.id (Scopus ID: 57209340626) \\ 22Email: mysrsaid@gmail.com (Scopus ID: 57209336516)
}

\begin{abstract}
The development of FinTech raises discourse on the vulnerability to cybercrimes in creditbased systems. This article addressed the topic on how OJK's non-penal policy dealing with the development of cyber crime in the financial sector. The legal research uses a normative (doctrinal) method with the conceptual and statute approach. The several theories used in analyzing the problems include: (1) Theory of Policy Making by Wayne Parson; (2) PublicPolicy System Theory; (3) Theory of Legal Classification by Philippe Nonet and Philip Selznick; (4) John Rawls Theory of Justice; and (5) Hukum Pembangunan Theory of Law by Mochtar Kusumaatmadja. The analysis shows that the non-penal policy was formed through the Risk Management system for cyber crime through fintech, but there are still some shortcomings related to the transition policy.
\end{abstract}

Keywords: FinTech; Legal Theory; Public policy; Economy

\begin{abstract}
Abstrak
Hadirnya FinTech memunculkan diskursus mengenai kerentanannya terhadap kejahatan cyber dalam FinTech berbasis kredit. Adapun artikel ini berusaha menjawab bagaimana kebijakan kriminal non-penal OJK dalam mengatasi kejahatan cyber dalam perkembangan teknologi dibidang keuangan dalam perspektif Teori Hukum. Metode hukum yang digunakan dalam penelitian ini adalah normative legal research dengan Pendekatan konseptual (conceptual approach) dan perundang-undangan (statute approach). Adapun beberapa teori yang dipergunakan dalam menganalisis permasalahan yang dikaji ini antara lain: (1) Teori Pembuatan Kebijakan oleh Wayne Parson; (2) Teori Sistem Kebijakan Publik; (3) Teori Klasifikasi Hukum oleh Philippe Nonet dan Philip Selznick; (4) Teori Keadilan John Rawls; dan (5) Teori Hukum Pembangunan oleh Mochtar Kusumaatmadja. Hasil analisis menunjukan bahwa kebijakan kriminal non-penal dibentuk melalui sistem Managemen Resiko terhadap kejahatan cyber melalui fintech, namun masih terdapat beberapa kekurangan terkait kebijakan transisi yang diambil.
\end{abstract}

Kata Kunci: FinTech; Teori Hukum; Kebijakan Publik; Ekonomi 


\section{PENDAHULUAN}

Munculnya sistem keuangan digital memaksa penegak hukum untuk melakukan transisi pendekatan guna mendeteksi adanya delik pencucian uang di revolusi keuangan digital saat ini. Layanan keuangan digital saat ini telah banyak beredar di Indonesia dan di negara-negara maju seperti Amerika, Jepang, China, Inggris dan lain sebagainya. Layanan Keuangan berbasis teknologi yang sering disebut dengan FinTech terbagi menjadi beberapa jenis seperti FinTech yang memiliki beragam penawaran produk kepada nasabahnya seperti FinTech berbasis pada pembayaran (payments), perencanaan keuangan (financial planning), pembiayaan (lending), dan investasi (investment) semakin menarik minat masyarakat dalam memenuhi kebutuhan tanpa berfikir lebih jauh.

Perkembangan teknologi dan informasi di era Revolusi Industri 4.0 telah mempengaruhi perindustrian secara langsung. Inovasi yang bersifat "disruptive" ini tentunya membawa kemudahan bagi masyarakat sebagai debitor dalam layanan financial service dengan layanan yang baru dan lebih baik, serta bersifat innovative mengungguli layanan konvensional. Adapun seiring munculnya terobosan yang bersifat disruptive maka tuntutan akan kebijakan hukum guna menghindari kekosongan hukum (rechtsvacuum) juga muncul.

Financial Technology atau FinTech ${ }^{1}$, mulai mengalami kenaikan popularitas dalam dunia industri. Dengan adanya inovasi ini, maka layanan jasa keuangan mulai mengalami gelombang inovasi teknologi, disruptive proses, dan transformasi bisnis, yang berdampak pada lahirnya the new economy playbook untuk para pelaku usaha. ${ }^{2}$

Lebih lanjut, data menunjukan ada lebih dari 9.000 FinTech providers di dunia. $^{3}$ Selain itu berdasarkan statistik

\footnotetext{
${ }^{1}$ Fintech adalah kepanjangan dari financial technology yang digambarkan sebagai "an emerging financial services sector in the 21 st century". Pada mulanya, istilah ini dipergunakan untuk menggambarkan transaksi antara konsumen dan institusi penyedia layanan keuangan. Akan tetapi kemudian istilah ini telah diperluas terhadap setiap inovasi teknologi dibidang keuangan seperti halnya crypto-currencies (Bitcoin). Lihat Investopedia. Fintech (definition). New York, December 2017. Lebih lanjut, menurut Kamus Mirriam-Webster, FinTech didefinisikan sebagai "products and companies that employ newly developed digital and online technologies in the banking and financial services industries". Dapat diakses pada https://www.merriamwebster.com/dictionary/fintech

2 Clemons, E.K.; Croson, D.C.; and Weber, B.W. "Market dominance as a precursor of a firm's failure: Emerging technologies and the competitive advantage of new entrants". Journal of Management Information Systems 13, 2 (Fall 1996), 59-75.

Berdasarkan data dari Crunchbase setidaknya sekarang ada lebih dari 9.000 FinTech service dan 9.807 pendiri start-ups diseluruh dunia.
} 
terbaru ${ }^{4}$ menunjukan dari 1.537 perusahaan di 64 Negara telah memperoleh pendanaan sebesar US\$80.4 Milyar dari para investor. Layanan Financial Technology mempunyai kelebihan dalam memberikan akses yang lebih mudah dan terjangkau bagi UMKM, khususnya dalam layanan pengkreditan seperti Peer to Peer (P2P) Lending.

Akan tetapi hadirnya FinTech memunculkan diskursus mengenai kerentanannya terhadap kejahatan cyber. Adapun artikel ini berusaha menjawab bagaimana kebijakan hukum Indonesia dalam mengatasi perkembangan teknologi informasi dibidang keuangan pada Revolusi Industri 4.0 saat ini.

\section{RUMUSAN MASALAH}

Berdasarkan latar belakang tersebut maka yang menjadi rumusan masalah dalam kajian ini adalah untuk mengetahui Bagaimana kebijakan kriminal non-penal OJK mengatur mengenai pencegahan kejahatan cyber dalam perkembangan jasa keuangan digital ditinjau dari teori-teori hukum terkait?

\footnotetext{
Untuk informasi lebih lanjut lihat https://www.crunchbase.com/hub/fintechcompanies\#section-overview

${ }^{4}$ Venture Scanner. Start-up market reports and data. San Francisco, CA, December 2017.
}

\section{METODE PENELITIAN}

Penelitian hukum yang digunakan dalam penelitian ini adalah penelitian hukum normative (normative legal research). Metode ini dipilih karena obyek kajian penelitian adalah mengenai asas dan prinsip hukum, kaidah hukum, teori dan doktrin hukum dari para ahli hukum. ${ }^{5}$ Peter Mahmud Marzuki menjelaskan penelitian hukum normatif (Penelitian Hukum) adalah:

“.. suatu proses untuk menemukan suatu aturan hukum, prinsip prinsip hukum, maupun doktrin-doktrin hukum untuk menjawab permasalahan hukum yang dihadapi. ... Penelitian hukum normatif dilakukan untuk menghasilkan argumentasi, teori atau konsep baru sebagai preskripsi dalam menyelesaikan masalah yang dihadapi. ${ }^{6}$

Mengingat bahwa ilmu hukum berusaha untuk menampilkan hukum secara integral sesuai dengan kebutuhan kajian ilmu hukum itu sendiri. ${ }^{7}$ Maka konteks penelitian ini dilakukan untuk membangun argumentasi, teori dan konsep baru mengenai delik pencucian uang di Indonesia. Adapun penelitian ini juga

5 Mukti Fajar dan Yulianto Ahmad, (2010), Dualisme Penelitian Hukum: Normatif dan Empiriris, Yogyakarta: Pustaka Pelajar, hlm. 33- 38

6 Peter Mahmud Marzuki, (2005), Penelitian Hukum, Jakarta: Kencana., hlm. 35

7 Yati Nurhayati, "Perdebatan Antara Metode Normatif Dengan Metode Empirik Dalam Penelitian Ilmu Hukum Ditinjau Dari Karakter, Fungsi, dan Tujuan Ilmu Hukum" Jurnal Al Adl, Vol 5, No 10 (2013), hlm. 15 
menggunakan beberapa pendekatan antara lain: Pendekatan konseptual (conceptual approach), Pendekatan perundangundangan (statute approach), dan pendekatan kasus (case approach).

Soerjono Soekanto dan Sri Mamudji memperkuat pendapat mengenai penelitian normatif adalah penelitian yang dilakukan dengan cara meneliti: ${ }^{8}$

a. Penelitian terhadap asas-asas hokum, yaitu penelitiian terhadap unsur-unsur hukum baik unsur ideal (normwissenschaft

sollenwissenschaft) yang menghasilkan kaidah-kaidah hukum melalui filsafat hukum dan unsur real (tatsachenwissenschaft / seinwissenschaft) yang menghasilkan tata hukum tertentu (tertulis).

b. Penelitian terhadap sistematika hukum, yaitu mengadakan identifikasi terhadap pengertian pokok dalam hukum seperti subyek hukum, hak dan kewajiban, peristiwa hukum dalam peraturan perundangan.

c. Penelitian terhadap taraf sinkronisasi vertikal dan horizontal, yaitu meneliti keserasian hukum

8 Soerjono Soekanto dan Sri Mamuji, (1995), Penelitian Hukum Normatif , Suatu Tinjauan Singkat, Jakarta: RajaGrafindo, hlm. 15. positif (peraturan perundagan) agar tidak bertentangan berdasarkan hierarki perundang-undangan (stufenbau theory).

d. Perbandingan hukum, yaitu membangun pengetahuan umum mengenai hukum positif dengan membandingkan sistem hukum di satu negara dengan sistem hukum di negara lainnya

e. Sejarah hukum, yaitu meneliti perkembangan hukum positif (peraturan perundagan) dalam kurun waktu tertentu (misalnya hukum tanah, perkawinan, perpajakan perusahaan dsb).

Sementara itu Sutadnyo Wigyosubroto memberikan istilah: "penelitian hukum normatif dengan istilah penelitian doktrinal, yaitu penelitian terhadap hukum yang dikonsepkan dan dikembangkan atas dasar doktrin yang dianut sang pengkonsep atau sang pengembangnya."

Penelitian hukum doktrinal tersebut dibagi menjadi 3 bagian, yaitu: a. Penelitian doktrinal yang mengkaji hukum yang dikonsepkan sebagai asas hukum alam dalam sistem moral menurut doktrin hukum alam. 
b. Penelitian doktrinal yang berupa kriminalisasi yang berlebihan mengkaji hukum yang dikonsepkan sebagai kaidah perundang-undangan menurut doktrin positivisme

c. Penelitian doktrinal yang mengkaji hukum yang dikonsepkan sebagai keputusan hakim in concreto menurut doktrin realisme

(oever criminalisation), yang justru mengurangi wibawa hukum. ${ }^{9}$

Pada prinsipnya kebijakan kriminal merupakan kajian yang luas yang terdiri dari kebijakan penal dan kebijakan nonpenal. Hal ini merujuk pada upaya penanggulangan kejahatan menurut $\mathrm{G} P$. Hoefnagels, yaitu ${ }^{10}$ :

1. penerapan hukum pidana (criminal law application);

\section{PEMBAHASAN}

\section{Konsep Kebijakan Kriminal Non-Penal}

Sebagai Upaya Preventif Kejahatan

Kebijakan kriminal seringkali dimaknai hanya sebatas kebijakan penal yang berkaitan dengan masalah kriminalisasi yaitu perbuatan apa yang dijadikan tindak pidana dan penalisasi yaitu sanksi apa yang sebaiknya dikenakan pada si pelaku tindak pidana. Kriminalisasi dan penaliasi mencakup lingkup perbuatan melawan hukum (actus reus), pertanggungjawaban pidana (mens rea) maupun sanksi yang dapat dijatuhkan baik berupa pidana (punishment) maupun tindakan (treatment). Sementara dalam ajaran hukum pidana secara umum kriminalisasi harus dilakukan secara hatihati, jangan sampai menimbulkan kesan represif yang melanggar asas ultimum remedium (ultima ratio principle) dan menjadi bumerang dalam kehidupan sosial
2. pencegahan tanpa pidana

(prevention without punishment);

3. mempengaruhi pandangan masyarakat tentang kejahatan dan pemidanaan melalui media masa (influencing views of society on crime and mass media)

Sehingga, penanggulangan kejahatan pada intinya terdiri dari dua hal pokok, yaitu pendekatan penal dan pendekatan non penal. Jika pendekatan pertama yang ditempuh, maka ini berarti bahwa penanggulangan suatu kejahatan dilakukan dengan menggunakan hukum pidana yang difungsikan sebagai sarana pengendali sosial, yaitu dengan sanksinya yang berupa pidana untuk dijadikan sarana menanggulangi kejahatan. Dengan

9 Muladi, (2003), Kebijakan Kriminal terhadap Cybercrime, Majalah Media Hukum Vol. 1 No. 3 tanggal 22 Agustus 2003, hlm. 1-2

10 Barda Nawawi Arif, (2002), Bunga Rampai Kebijakan Hukum Pidana, Bandung: Citra Aditya Bakti, hlm. 48 
demikian diharapkan norma-norma sosial dapat ditegakkan dengan sanksi yang dimiliki hukum pidana terhadap seseorang yang berperilaku tidak sesuai dengan norma-norma tersebut.

Secara umum, substansi hukum penal dalam wujudnya sebagai peraturan perundang-undangan, telah diterima sebagai instrumen resmi yang memperoleh aspirasi untuk dikembangkan, yang diorientasikan secara pragmatis untuk menghadapi masalah-masalah sosial (kejahatan) yang kontemporer. Hukum demikian dinamakan hukum responsif yang menampakkan ciri bahwa hukum ada bukan demi hukum itu sendiri, bukan demi kepentingan praktisi hukum, juga bukan untuk membuat pemerintah senang, melainkan hukum ada demi kepentingan rakyat di dalam masyarakat. ${ }^{11}$

Terdapat ungkapan menarik Satjipto Rahardjo," Hukum adalah untuk manusia bukan sebaliknya manusia untuk hukum". ${ }^{12}$ Hal ini berarti, hukum bisa diibaratkan sebagai papan

11 Max Weber dalam A.A.G. Peters dan Koesriani Siswosoebroto, (1998), Hukum dan Perkembangan Sosial, Jakarta: Sinar Harapan, hlm. 483

12 Satjipto Rahardjo, (2006), "Hukum Progresif, Kesinambungan, Merobohkan, dan Membangun", Jurnal Hukum Progresif, Program Doktor Ilmu Hukum Undip, edisi 2 April 2006, hlm. 20. petunjuk, yang selalu memperingatkan, membebaskan, dan sebagai alat untuk melayani serta mencapai tujuan manusia. Bertolak dari pemikiran Satjipto Rahardjo di atas, hukum sebagai hasil karya manusia mencerminkan sekumpulan kehendak dan sasaran-sasaran yang ingin dicapai. Atas dasar itulah muncul kebijakan kriminal non-penal.

Selanjutnya, Muladi menyatakan, bahwa penegakan hukum pidana bukan merupakan satu-satunya tumpuan harapan untuk dapat menyelesaikan atau menanggulangi kejahatan secara tuntas. Hal ini wajar karena pada hakikatnya kejahatan itu merupakan "masalah kemanusiaan" dan "masalah sosial" yang tidak dapat di atasi semata-mata dengan hukum pidana sebagai suatu masalah sosial, kejahatan merupakan suatu fenomena kemasyarakatan yang dinamis, yang selalu tumbuh dan terkait dengan fenomena dan struktur kemasyarakatan lainnya yang sangat kompleks. ${ }^{13}$

Bertitik tolak dari pendapat Muladi tersebut di atas, dapat dipastikan, bahwa hukum pidana bukan merupakan satusatunya tumpuan harapan untuk dapat menyelesaikan atau menanggulangi

13 Muladi, (1995), Kapita Selekta Sistim Peradilan Pidana, Semarang: Badan Penerbit UNDIP, hlm. 7 
kejahatan secara tuntas, sehingga diperlukan upaya lain selain upaya penal dalam menanggulangi masalah kejahatan. Selain Muladi, ada beberapa pendapat yang memberi pendapat senada diantaranya Donald R. Taf dan Ralp W. England, menyatakan bahwa efektivitas hukum pidana tidak dapat diukur secara akurat. $^{14}$

Maka dapat disimpulkan, bahwa kebijakan penal sebagai salah satu sarana penanggulangan kejahatan memiliki keterbatasan-keterbatasan. Sehingga, diperlukan upaya lain yang dilakukan untuk menanggulangi kejahatan. Upaya lain selain hukum pidana yang berusaha menanggulangi kejahatan inilah kemudian dapat dikatakan sebagai upaya "non penal”, yaitu suatu upaya rasional dalam menanggulangi kejahatan dengan upayaupaya lain selain hukum pidana (penal). Oleh karena itu dilihat dari kebijakan kriminal sebaiknya ditempuh dengan pedekatan kebijakan integral, baik dengan menggunakan "penal" maupun dengan sarana "non-penal".

${ }^{14}$ Donald R. Taft and Ralph W. England, (1964), Criminology, hlm. 315, dalam Barda Nawawi Arief, (2005), Beberapa Aspek Kebijakan Penegakan dan Pengembangan Hukum Pidana, Bandung: Citra Aditya Bakti, hlm. 69-70
Kebijakan Non-Penal OJK Melalui Managemen Resiko Terhadap Kejahatan Cyber

Managemen Resiko Terhadap Tindak Pidana Pencucian Uang dalam $P 2 P$ Lending diatur didalam Pasal 42 Peraturan OJK No. 77/POJK.01/2016 yang mewajibkan bahwa FinTech P2P harus menerapkan prinsip Anti-Money Laundering (AML) \& Counter Fund Terrorism (CFT) berdasarkan peraturan terkait. Adapun peraturan terkait hal ini $\begin{array}{llll}\text { adalah } & \text { Peraturan } & \text { OJK } & \text { No. }\end{array}$ 12/POJK/01/2017 sebagaimana diubah dengan Peraturan OJK No. 23 /POJK.01/2019. Ruang lingkup managemen resiko berdasarkan Peraturan OJK No.12/POJK.01/ 2017, yakni:

1) Identifikasi;

2) Verifikasi identitas calon konsumen; dan

3) Pengawasan transaksi.

Berdasarkan Penjelasan Peraturan OJK Nomor 12/POJK.01/2017 Tentang Penerapan Program Anti Pencucian Uang dan Pencegahan Pendanaan Terorisme dijelaskan bahwa lahirnya kebijakan ini dilatarbelakangi oleh adanya globalisasi di sektor jasa keuangan yang diiringi dengan semakin berkembangnya produk jasa keuangan termasuk pemasarannya (multi channel marketing), konglomerasi, serta aktivitas dan teknologi industri jasa 
keuangan yang semakin kompleks baik dari sisi produk, layanan, dan penggunaan teknologi informasi, berpotensi meningkatkan risiko pemanfaatan industri jasa keuangan sebagai sarana Pencucian Uang dan Pendanaan Terorisme, dengan berbagai modus operandinya yang semakin beragam dan maju.

Kemudian dalam kaitan tersebut dan sesuai ketentuan Pasal 5 Undang Undang Nomor 21 Tahun 2011 tentang Otoritas Jasa Keuangan, yang menegaskan bahwa OJK berfungsi menyelenggarakan sistem pengaturan dan pengawasan yang terintegrasi terhadap keseluruhan kegiatan di dalam sektor jasa keuangan, perlu adanya pengaturan dan pengawasan yang terintegrasi (termasuk keseragaman pengaturan) dalam penerapan program anti Pencucian Uang dan pencegahan Pendanaan Terorisme (APU dan PPT) oleh PJK yang melakukan kegiatan di sektor jasa keuangan.

Disamping itu, pengaturan dan pengawasan yang terintegrasi dalam penerapan program APU dan PPT oleh PJK yang melakukan kegiatan di sektor jasa keuangan perlu kiranya didasarkan pada pengawasan berbasis risiko (risk based approach) sesuai dengan standar internasional sebagaimana direkomendasikan oleh The Financial Action Task Force on Money Laundering
(FATF) yang menegaskan agar dalam penerapan rezim anti Pencucian Uang dan pencegahan Pendanaan Terorisme perlu mengedepankan pendekatan berbasis risiko dalam penyusunan kebijakan dan prosedur. Dalam hal tingkat risiko Pencucian Uang dan/atau Pendanaan Terorisme tinggi maka kebijakan dan prosedur yang ditetapkan lebih ketat dibandingkan apabila tingkat risiko Pencucian Uang dan/atau Pendanaan Terorisme dinilai lebih rendah.

Berdasarkan rekomendasi FATF, Peraturan OJK perlu mengatur beberapa Rekomendasi FATF termasuk tetapi tidak terbatas pada pengaturan penerapan program APU dan PPT di sektor jasa keuangan berbasis risiko (risk based approach), seperti:

1. Kewajiban PJK melakukan penilaian risiko TPPU dan TPPT terkait dengan nasabah, negara atau area geografis, produk, jasa, transaksi, atau jaringan distribusi (delivery channels), yang menjadi dasar untuk mengelola dan memitigasi risiko;

2. Pengaturan CDD sederhana sesuai dengan penilaian risiko tersendiri oleh PJK yang dimungkinkan untuk dilakukan sepanjang: Pertama, memenuhi kriteria untuk nasabah atau transaksi berisiko rendah yang konsisten dengan penilaian risiko; dan Kedua, persyaratan CDD sederhana mampu mengelola tingkat ancaman TPPU dan/atau TPPT yang telah diidentifikasi dengan tingkat risiko rendah.

3. Persyaratan CDD sederhana tidak mencakup Nasabah yang 
berdasarkan peraturan perundangundangan dikategorikan sebagai Nasabah atau transaksi yang berisiko tinggi;

4. Pengaturan mengenai Politically Exposed Person (PEP), yang mencakup antara lain identifikasi dan verifikasi PEP domestik, PEP asing, orang yang diberi kewenangan untuk melakukan fungsi penting (prominent function) dalam lembaga/organisasi internasional, dan anggota keluarga afiliasi/close associates dari PEP;

5. Pengaturan mengenai CDD terhadap penerima manfaat (beneficiary) dari asuransi jiwa/life insurance dan produk lain terkait asuransi, antara lain kewajiban untuk melakukan verifikasi identitas dari penerima manfaat (beneficiary) pada saat pembayaran klaim asuransi jiwa/life insurance; dan

6. Pengaturan kebijakan dan prosedur penerapan APU dan PPT bagi Konglomerasi Keuangan (financial group).

Melalui penerapan program Anti Pencucian Uang dan Pendanaan terorisme di sektor jasa keuangan yang berstandar internasional, diharapkan Penyedia Jasa Keuangan dapat melakukan kegiatannya secara lebih sehat dan lebih berdaya saing global sehingga pada akhirnya akan lebih mendorong pertumbuhan industri jasa keuangan secara nasional.

\section{Melalui Peraturan OJK Nomor} 12/POJK.01/2017, ketentuan-ketentuan terkait APU dan PPT yang diatur masingmasing sektor jasa keuangan baik
Perbankan, Pasar Modal, dan Industri Keuangan Non Bank diharmonisasi secara terpadu termasuk tetapi tidak terbatas antara lain pada perbedaan pengaturan antar masing-masing sektor jasa keuangan, independensi dan tanggung jawab penanggung jawab penerapan program APU dan PPT, informasi dan dokumen pendukung prosedur Uji Tuntas Nasabah (Customer Due Diligence/CDD) dan Uji Tuntas Lanjut (Enhanced Due Diligence/EDD), serta pengenaan sanksi. Menunjuk pada adanya perkembangan produk dan layanan jasa keuangan yang dimaksudkan untuk menjawab kebutuhan masyarakat atas produk dan layanan jasa keuangan yang memanfaatkan perkembangan teknologi dan informasi, Peraturan OJK mengatur ketentuan. Pertama, pertemuan langsung (face to face) dan tanda tangan dokumen Calon Nasabah atau Nasabah dalam rangka CDD yang dimungkinkan dapat dilakukan secara elektronik melalui sistem yang disediakan oleh PJK. Kedua, prosedur CDD sederhana yang dimungkinkan apabila tujuan pembukaan rekening terkait dengan program Pemerintah dalam rangka peningkatan kesejahteraan masyarakat dan/atau pengentasan kemiskinan seperti layanan keuangan tanpa kantor dalam rangka keuangan inklusif, simpanan 
pelajar, dan bantuan sosial pada kementerian negara/lembaga.

Selain itu, dalam rangka upaya penegakan hukum terkait dengan penerapan program APU dan PPT di sektor jasa keuangan, Peraturan OJK mengatur mengenai keseragaman sanksi atas pelanggaran Peraturan OJK Nomor 12/POJK.01/2017 dengan tetap memperhatikan size Penyedia Jasa Keuangan masing masing sektor jasa keuangan dimana sanksi terbagi menjadi sanksi berupa denda atas pelanggaran kewajiban pelaporan.

Adanya Peraturan OJK Nomor 12/POJK.01/2017 Tentang Penerapan Program Anti Pencucian Uang dan Pencegahan Pendanaan Terorisme di Sektor Jasa Keuangan sebagaimana diubah dengan Peraturan OJK Nomor 23 /POJK.01/2019 telah mengakomodir kebijakan integral antara kebijakan non penal dari OJK dengan kebijakan penal pada Undang-Undang Nomor 8 Tahun 2010 tentang Pencegahan dan Pemberantasan Tindak Pidana Pencucian Uang.

Akan tetapi adanya pengaturan tentang ketentuan peralihan pada Pasal 67 ayat (2) Peraturan OJK Nomor 12/POJK.01/2017 tentang Penerapan Program Anti Pencucian Uang dan Pencegahan Pendanaan Terorisme di
Sektor Jasa mengatur bahwa bagi LKM dan penyelenggara layanan pinjam meminjam uang berbasis teknologi informasi, ketentuan pada Peraturan OJK ini dinyatakan berlaku setelah 4 (empat) tahun terhitung sejak Peraturan OJK ini diundangkan. Sehingga terhadap FinTech berbasis Peer to Peer Lending Kebijakan non-penal OJK ini hanya akan diberlakukan setelah tahun 2021. Menjadikan masih terbukanya potensi pencucian uang secara cyber menggunakan sarana tersebut.

\section{Analisis Teoritik Kebijakan Transisi Peer to Peer Lending oleh OJK}

Perkembangan besar FinTech di Indonesia dan tuntutan akademisi dan praktisi hukum telah mendorong Otoritas Jasa Keuangan (OJK) untuk mengambil kebijakan terkait praktek FinTech di Indonesia. Sejak tahun 2016, pasar Indonesia telah diserbu oleh perusahaan start-ups yang merevolusi transaksi berbasis teknologi. Sehingga untuk mendukung pertumbuhan FinTech di Indonesia terutama Peer to Peer Lending, Maka, Otoritas Jasa Keuangan (OJK) menerbitkan kebijakan tersebut kedalam beberapa regulasi antara lain:

1. Peraturan OJK No. 77/POJK.01/2016 tentang Layanan 
Pinjam Meminjam Uang Berbasis

Teknologi Informasi;

2. Peraturan OJK No. 12 /POJK.01/2017 tentang Penerapan Program Anti Pencucian Uang (AML) dan Pencegahan Pendanaan Terorisme (CFT) di Sektor Jasa Keuangan sebagaimana diubah dengan Peraturan OJK No. 23 /POJK.01/2019; dan

3. Peraturan OJK No. 13/POJK.02/2018 tentang Inovasi Keuangan Digital di Sektor Jasa Keuangan.

Dalam hal ini apabila dikaji berdasarkan teori Pembuatan Kebijakan (Policy-Making) oleh Wayne Parson bahwa proses pembuatan kebijakan didasarkan pada tiga tahapan, yakni ${ }^{15}$ :

a. Tahap Meta Pembuatan Kebijakan Publik (Metapolicymalthzgsfage);

b. Tahap Pembuatan Kebijakan Publik (Policy-making stage); dan

c. Tahap Pasca Pembuatan Kebijakan Publik (Post-policy-making stage)

Maka dapat ditarik analisis bahwa Otoritas Jasa Keuangan telah melaksanakan dua tahapan yakni tahapan Meta Pembuatan Kebijakan Publik dan

15 Wayne Parsons, (2004). "Not Just Steering but Weaving: Relevant Knowledge and the Craft of Building Policy Capacity and Coherence". Australian Journal of Public Administration, vol.63 No.1, hlm. 43-57.
Tahapan Pembuatan Kebijakan Publik. Adapun OJK dalam hal ini masih melaksanakan tahap yang ketiga yakni Tahap Pasca Pembuatan Kebijakan Publik yang ditandai dengan evaluasi proses pembuatan kebijakan publik yang telah dilakukan dan melakukan umpan balik atas kebijakan melalui Program Regulatory Sandbox.

Selanjutnya apabila dikaji dari Teori Sistem Kebijakan Publik bahwa keseluruhan pola kelembagaan dalam pembuatan kebijakan publik yang melibatkan hubungan diantara 4 elemen, adapun elemen dalam pembentukan peraturan OJS terkait FinTech ini, yaitu :

a. Input: bahwa perkembangan teknologi dan informasi merevolusi kegiatan transaksi dan kegiatan pinjam meminjam secara online, kemudian ada concern terkait rentannya start-ups FinTech yang tanpa pengawasan untuk digunakan sebagai media cyber laundering dan pendanaan terorisme;

b. Process: adapun dalam proses pembentukan kebijakan kedalam peraturan OJK melibatkan kelompok antara lain Otoritas Jasa Keuangan dan stake holder terkait;

c. Output: adapun dengan beberapa proses tersebut maka dibentuklah 
serangkaian peraturan yakni

Peraturan

OJK

No.

77/POJK.01/2016 tentang Layanan

Pinjam Meminjam Uang Berbasis

Teknologi Informasi, Peraturan

OJK No. 12 /POJK.01/2017

tentang Penerapan Program Anti

Pencucian Uang (AML) dan

Pencegahan Pendanaan Terorisme

(CFT) di Sektor Jasa Keuangan, dan Peraturan OJK No.

13/POJK.02/2018 tentang Inovasi

Keuangan Digital di Sektor Jasa

Keuangan untuk menjawab

permasalahan terkait kekosongan

hukum untuk FinTech.

d. Impact: Bahwa dengan adanya beberapa peraturan tersebut berdampak pada adanya pengawasan dan regulatory sandbox guna menjamin transparansi dan legalitas FinTech. Selanjutnya ada ratusan FinTech illegal ditutup setelah adanya peraturan ini. ${ }^{16}$

Managemen Resiko Terhadap Tindak Pidana Pencucian Uang dalam $P 2 P$

16 Adapun penutupan FinTech illegal terbaru dapat dilihat pada tulisan Nur Rohmi Aida tertanggal 07/09/2019, di Kompas, dengan judul “OJK Tutup 123 Fintech Ilegal, Apa Saja? Cek Daftarnya!" lihat selengkapnya di https://www.kompas.com/tren/read/2019/09/07/134 826765/ojk-tutup-123-fintech-ilegal-apa-saja-cekdaftarnya?page $=$ all.
Lending diatur didalam Pasal 42 Peraturan

OJK No. 77/POJK.01/2016 yang mewajibkan bahwa FinTech $\mathrm{P} 2 \mathrm{P}$ harus menerapkan prinsip Anti-Money Laundering (AML) \& Counter Fund Terrorism (CFT) berdasarkan peraturan terkait. $^{17}$ Walaupun Peraturan OJK No.12/POJK.01/2017 sebagaimana diubah dengan Peraturan OJK No. 23 /POJK.01/2019, telah mengatur mengenai pencegahan tindak pidana pencucian uang secara cyber dan pencegahan pendanaan terorisme. Namun, menurut OJK, FinTech P2P Lending hanya akan diwajibkan untuk mengikuti ketentuan ini sejak 2021 nanti, dengan alasan untuk memberikan ruang bagi bisnis ini untuk tumbuh dan berkembang di Indonesia. $^{18}$ Sementara peraturan untuk $\mathrm{P} 2 \mathrm{P}$ hanya dapat diberlakukan setelah 2021, sistem monitoring transaksi seharusnya tetap wajib diberlakukan. Dengan demikian sangat disayangkan bahwa FinTech P2P masih potensial menjadi sarana TPPU

17 Ruang lingkup managemen resiko berdasarkan Peraturan OJK No.12/POJK.01/ 2017, yakni (1) Identifikasi; (2) Verifikasi identitas calon konsumen; (3) Pengawasan transaksi.

18 Hukumonline: "Meraba Potensi TPPU di Industri Fintech," terbitan 28 Maret 2019. selengkapnya di website https://www.hukumonline.com/berita/baca /lt5c9c73ce3720d/meraba-potensi-tppu-di-industrifintech 
karena ketiadaan protocol AML yang diberlakukan. ${ }^{19}$

Mengingat Teori Klasifikasi Hukum oleh Philippe Nonet dan Philip Selznick $^{20}$ maka Peraturan-Peraturan OJK yang dibentuk ini masih berfungsi sebagai fasilitator dari berbagai respon terhadap kebutuhan dan aspirasi sosial (hukum responsif) yang dibuktikan dengan adanya penundaan pemberlakuan peraturan agar FinTech dapat berkembang sesuai kebutuhan masyarakat. Terlebih memang tidak bisa dipungkiri disatu sisi negara membutuhkan investor yang muncul dengan adanya perkembangan ini, terlebih mengingat Pemerintah yang kebijakan investasinya berubah-ubah dengan cepat atau tidak transparan dalam perundingan bisnis, telah kesulitan untuk menarik modal skala besar ke Indonesia. Namun disisi lain juga tidak kalah penting adanya suatu kewajiban negara untuk melakukan kontrol terhadap potensi kejahatan. ${ }^{21}$

19 Hukum Online, "Managing MoneyLaundering Risk for Financial Technology P2P Lending Companies", terbitan 31 Mei 2019, di https://pro.hukumonline.com/o/lt5cf129a1b25bc /managing-money-laundering-risk-for-financialtechnology-p2p-lending-companies

${ }^{20}$ Nonet, Selznick, \& Kagan, (2017), Law and Society in Transition: Toward Responsive Law, New York: Routledge, hlm.29 dan 73.

21 Ali Amrin, Dadang Abdullah, dan M.Yasir Said, (2019), "Kebijakan Pemerintah Yang Menjamin Kepastian Hukum Dalam Berinvestasi Di Daerah", Prosiding Seminar Nasional Lingkungan Lahan Basah, Vol.4, Issue.2, (2019), hlm. 369-372
Namun menurut hemat penulis dalam kaitannya dengan tindak pidana dalam bentuk serious crime dan extraordinary crime seperti halnya TPPU dan Pendanaan Terorisme maka perlu dipahami bahwa skala prioritas harus lebih mengutamakan ketahanan sosial dan tujuan negara (raison d'etat) yang dalam kasus ini hanya akan dapat dicapai melalui kebijakan hukum yang represif, maka sebagaimana amanat Hukum Pidana Indonesia, penanggulangan dan pemberantasan TPPU dan Pendanaan Terorisme merupakan prioritas yang lebih penting dibandingkan pengembangan startup bisnis, karena menyangkut ketahanan dan stabilitas nasional.

Adapun selanjutnya sebagaimana dikemukakan Rawls dalam bukunya "A Theory of Justice" bahwa teori keadilan merupakan suatu metode untuk mempelajari dan menghasilkan keadilan. Ada prosedur-prosedur berfikir untuk menghasilkan keadilan. Dalam hal ini Rawls mengemukakan bahwa different principles hanya akan bekerja jika prinsip pertama bekerja atau dengan kata lain prinsip perbedaan akan bekerja jika basic right terpenuhi. ${ }^{22}$ Menurut hemat penulis dalam prinsip Rawls ini ditekankan harus

22 John Rawls, (2009), "A Theory of Justice", Revised Edition, USA: Harvard University Press, hlm. 4-5. 
ada pemenuhan sesuatu yang lebih dasar sehingga sesuatu yang lain dapat dipenuhi. Sehingga dengan kata lain peningkatan ekonomi dan kesejahteraan masyarakat hanya akan tercapai jika sesuatu yang lebih mendasar sudah terpenuhi dalam hal ini termasuk penegakan hukum vital negara terhadap kejahatan yang merugikan perekonomian.

Terakhir mengutip Teori Profesor Mochtar Kusumaatmadja mengenai Hukum Pembangunan. Sebenarnya Hukum Pembangunan bukanlah sebuah "teori" melainkan "konsep" pembinaan hukum yang dimodifikasi dan diadaptasi dari teori Roscoe Pound "Law as a tool of social engineering" yang berkembang di Amerika Serikat. Profesor Mochtar Kusumaatmadja mengolah semua masukan tersebut dan menyesuaikannya pada kondisi Indonesia. ${ }^{23}$ Ada sisi menarik dari teori ini dimana diperlihatkan betapa pentingnya kerja sama antara pengemban hukum teoritis dan penstudi pada umumnya (scholars) serta pengemban hukum praktis (specialists in decision) dalam proses melahirkan suatu kebijakan publik, yang di satu sisi efektif secara politis, namun di sisi lainnya juga bersifat mencerahkan. Oleh karena itu maka Teori

\footnotetext{
23 Shidarta, (2006), Karakteristik Penalaran Hukum Dalam Konteks Ke-Indonesiaan, Jakarta: CV Utomo, hlm. 411.
}

Hukum Pembangunan dari Mochtar Kusumaatmadja memperagakan pola kerja sama dengan melibatkan keseluruhan stakeholders yang ada dalam komunitas sosial dalam proses pencapaian tujuan pragmatis (demi pembangunan).

\section{PENUTUP}

Kebijakan kriminal non-penal dibentuk melalui sistem Managemen Resiko terhadap kejahatan cyber melalui fintech yang diatur didalam Pasal 42 Peraturan OJK No. 77/POJK.01/2016 yang mewajibkan prinsip-prinsip Anti-Money Laundering (AML) \& Counter Fund Terrorism (CFT) sebagaimana diatur dalam OJK No.12/POJK.01/2017 sebagaimana diubah dengan Peraturan OJK No. 23 /POJK.01/2019. Ruang lingkup managemen resiko ini meliputi: (1) Identifikasi; (3) Verifikasi identitas calon konsumen; dan (4) Pengawasan transaksi.

Walaupun Peraturan OJK, telah mengatur mengenai pencegahan kejahatan cyber. Namun, FinTech P2P Lending hanya akan diwajibkan untuk mengikuti ketentuan ini sejak 2021, dengan alasan untuk memberikan ruang transisi untuk tumbuh dan berkembang di Indonesia. Sementara berdasarkan analisis terkait teori-teori hukum terkait, sistem monitoring transaksi seharusnya tetap wajib diberlakukan sebagai upaya 
eradikasi kriminal. Dengan demikian sangat disayangkan bahwa sistem Peer to Peer Lending masih berpotensi menjadi sarana kejahatan cyber karena ketiadaan preventive protocol yang diberlakukan.

\section{DAFTAR PUSTAKA}

\section{BUKU}

A.A.G. Peters dan Koesriani Siswosoebroto, (1998), Hukum dan Perkembangan Sosial, Jakarta: Sinar Harapan

Barda Nawawi Arif, (2002), Bunga Rampai Kebijakan Hukum Pidana, Bandung: Citra Aditya Bakti.

Donald R. Taft and Ralph W. England, (1964), Criminology, dalam Barda Nawawi Arief, (2005), Beberapa Aspek Kebijakan Penegakan dan Pengembangan Hukum Pidana, Bandung: Citra Aditya Bakti

John Rawls, (2009), "A Theory of Justice", Revised Edition, USA: Harvard University Press.

Muladi, (1995), Kapita Selekta Sistim Peradilan Pidana, Semarang: Badan Penerbit UNDIP

Mukti Fajar dan Yulianto Ahmad, (2010), Dualisme Penelitian Hukum: Normatif dan Empiriris, Yogyakarta: Pustaka Pelajar.

Nonet, Selznick, \& Kagan, (2017), Law and Society in Transition: Toward Responsive Law, New York: Routledge.

Peter Mahmud Marzuki, (2005), Penelitian Hukum, Jakarta: Kencana.
Shidarta, (2006), Karakteristik Penalaran Hukum Dalam Konteks KeIndonesiaan, Jakarta: CV Utomo.

\section{JURNAL DAN HASIL PENELITIAN}

Ali Amrin, Dadang Abdullah, dan M.Yasir Said, (2019), "Kebijakan Pemerintah Yang Menjamin Kepastian Hukum Dalam Berinvestasi Di Daerah", Prosiding Seminar Nasional Lingkungan Lahan Basah, Vol.4, Issue.2, (2019), hlm. 369-372

Clemons, E.K.; Croson, D.C.; and Weber, B.W. "Market dominance as a precursor of a firm's failure: Emerging technologies and the competitive advantage of new entrants". Journal of Management Information Systems 13, 2 (Fall 1996).

Muladi, (2003), Kebijakan Kriminal terhadap Cybercrime, Majalah Media Hukum Vol. 1 No. 3 tanggal 22 Agustus 2003

Satjipto Rahardjo, (2006), "Hukum Progresif, Kesinambungan, Merobohkan, dan Membangun", Jurnal Hukum Progresif, Program Doktor Ilmu Hukum Undip, edisi 2 April 2006

Venture Scanner. "Start-up Market Reports and Data". San Francisco, CA, December 2017.

Wayne Parsons, (2004). "Not Just Steering But Weaving: Relevant Knowledge and the Craft of Building Policy Capacity and Coherence". Australian Journal of Public Administration, Vol.63 No.1 
Yati Nurhayati, "Perdebatan Antara intech-companies\#sectionMetode Normatif Dengan overview

Metode Empirik Dalam

Penelitian Ilmu Hukum

Ditinjau Dari Karakter, Fungsi, dan Tujuan Ilmu Hukum" Jurnal Al Adl, Vol 5, No 10 (2013)

\section{WEBSITE DAN MEDIA MASA}

Hukumonline: "Meraba Potensi TPPU di Industri Fintech," terbitan 28 Maret 2019. selengkapnya di website

https://www.hukumonline.com /berita/baca /1t5c9c73ce $3720 \mathrm{~d} /$ merabapotensi-tppu-di-industri-fintech

Hukumonline, "Managing MoneyLaundering Risk for Financial Technology P2P Lending Companies", terbitan 31 Mei 2019 ,

https://pro.hukumonline.com/o/ 1t5cf129a1b25bc /managingmoney-laundering-risk-forfinancial-technology-p2plending-companies

Kompas Edisi 07/09/2019, dengan judul "OJK Tutup 123 Fintech Ilegal, Apa Saja? Cek Daftarnya!" lihat selengkapnya di https://www.kompas.com/tren/ read/2019/09/07/134826765/oj k-tutup-123-fintech-ilegal-apasaja-cek-daftarnya?page $=$ all .

Kamus Mirriam-Webster dapat diakses secara online pada https://www.merriamwebster.com/dictionary/fintech

Crunchbase, "Fintech Companies" dapat diakses melalui website pada https://www.crunchbase.com/hub/f 